Article

\title{
Normative Virtue Theory in Theological Ethics
}

\author{
Nicholas Austin \\ Heythrop College, University of London, Kensington Square, London W8 5HQ, UK; n.austin@heythrop.ac.uk \\ Received: 17 August 2017; Accepted: 18 September 2017; Published: 29 September 2017

\begin{abstract}
What place is there for virtue theory in theological ethics? Many question the normative significance of virtue theory in theological ethics today, leaving it to rule-based ethics to provide action-guidance. There are three key objections to the normativity of virtue theory: that virtue theory is about agents rather than actions, that virtue theory has nothing to say directly about the morality of actions, and that the virtues are too vague to be of normative or action-guiding significance. This essay, drawing on Thomas Aquinas's account of virtue, challenges these perceptions and argues for a genuinely normative, action-guiding virtue theory within theological ethics. Theological ethics, in turn, can contribute to virtue theory, especially by its emphasis on the ecstatic nature of mature moral virtue, and through its reflection on the virtue of spiritual discernment.
\end{abstract}

Keywords: virtue ethics; virtue theory; theological ethics; Thomas Aquinas; normative ethics

\section{Introduction}

Joseph Selling's Reframing Catholic Theological Ethics helpfully addresses what is sometimes called "Fundamental Moral Theology," the part of theological ethics that deals with the more foundational questions to do with method, law, virtue, conscience, and moral action (Selling 2016). Selling combines study of the moral theological tradition-especially through an analysis of the ethics of Thomas Aquinas (1224-1274), and a critique of his interpreters such as Cardinal Cajetan (also known as Tommaso De Vio) (1468-1534) — with engagement with contemporary ethics. Here, I would like to focus on one topic in foundational theological ethics to which Selling attends, namely, virtue, and its role in theological reflection on morals. What is at stake here is not merely what theological ethics can contribute to the understanding of virtue, but also what virtue theory can offer theological ethics.

The widespread adoption of virtue theory by Catholic moralists can be understood, at least in part, as a response to the weaknesses of the sin-focused manuals of moral theology. ${ }^{1}$ Catholic theological ethics, as is well known, has long been attempting to move beyond an atomistic focus on actions, that is, a distorting and blinkered concentration on individual acts divorced from the narrative of a person's life and the interior dispositions that are at the root of moral agency.(Mahoney 1987, pp. 1-36; Keenan 2008, pp. 9-34) Liberated by virtue theory, theological ethics, it is argued, can now confidently focus on the kind of persons we are called to become, rather than on parsing the species of mortal and venial $\sin ^{2}$ Yet, as is often the case, the corrective risks introducing its own imbalance. An approach that recommends exclusive focus on one's own virtue seems peculiarly self-centered for an ethical theory, especially one informed by the New Testament vision of selfless love. Moreover, there is the danger that a one-sided focus on the character of the moral agent fails to say anything meaningful about moral behavior itself. Virtue theory, it may be objected, defaults on the obligation incumbent on ethicists to offer normative guidance.

1 On virtue in contemporary Catholic theological ethics, see David Cloutier and William C. Mattison III, “Review Essay: The Resurgence of Virtue in Recent Moral Theology" (Cloutier and Mattison 2014).

2 For a recent argument that virtue ethics represents the best approach to theological ethics today, see Michael G. Lawler and Todd A. Salzman, “Virtue Ethics: Natural and Christian," (Lawler and Salzman 2013). 
Joseph Selling unwittingly adds fuel to this objection when he distinguishes in his book between "normative ethics", which is about applying rules to behavior, and "goal-centered ethics", which is about virtues and intentions (Selling 2016, pp. 10-12). This division-of-labor approach seems to suggest that all the renewal of virtue amounts to is an additional chapter in the moral textbooks, one that focuses on character, leaving it to other, rule-based chapters to deal with action and behavior. Yet, at the conclusion of his book, Selling holds open the possibility of a "convergence" between normative ethics and the more goal-centered, virtue-focused approach, into a "single method of ethical evaluation". He suggests, then, that a division of labor between the normative (that is, action guiding) aspects of theological ethics and virtue theory is based on a misguided dichotomy, and that their unification can result in "a fresh narrative about ethical living" (Selling 2016, p. 200). This is the suggestive insight that I would like to explore and develop, by defending more directly the normative significance of virtue theory within theological ethics. Virtue theory has the power to overcome the atomistic approach, not by shifting the focus, pendulum-like, from action to character, but rather by integrating reference to character into the moral evaluation of action.

If theological ethics needs virtue theory, does virtue theory need theological ethics? Today, there are many forms of virtue ethics other than the familiar neo-Aristotelian version (Carr et al. 2016). Like Selling, I take Thomas Aquinas's thinking about virtue to be an especially fruitful vein to mine, even in addressing contemporary questions in ethical theory, such as the relationship between the understanding of virtue and the resolution of particular moral decisions and issues. The riches of Aquinas's thinking about virtue arise, not merely from his often-perceptive reading of Aristotle, but also from particular emphases and insights from the theological tradition of which he is part. I shall attempt to point to theological resources integral to his ethics that help us form a more carefully calibrated account of the relationship of virtue theory and the ethical evaluation of action than is sometimes offered.

The argument for normative virtue theory will proceed by challenging what I perceive to be three common misconceptions about virtue theory: that virtue theory is about agents rather than actions, that virtue theory has nothing to directly say about the morality of actions, and that the virtues are too vague to be of normative or action-guiding significance.

\section{Agents, Acts, and Ecstasy}

The agent-focus of Aquinas's virtue theory is evident from his acceptance of the principle, agere sequitur esse, doing follows being. ${ }^{3}$ This is the basis for Aquinas's focus on the virtues and vices, for, "being is prior by nature to acting". ${ }^{4}$ While this principle is metaphysical in nature, Aquinas uses it to establish the necessity of the virtues:

The manner of action follows the disposition of the agent, since as a thing is, such are the actions it works. And therefore, since virtue is the principle of some kind of operation, it is necessary that there pre-exist in the agent, according to virtue, some corresponding disposition. ${ }^{5}$

In other words, the virtues are necessary precisely because to live justly, mercifully, and patiently, one needs to be just, merciful, and patient. If, as ethicists, we are interested in good and bad actions, we should therefore be interested in their principles in the disposition of the agent's mind, will, and emotions.

3 Commentary on the Sentences, lib. 3 d. 3 q. 2 a. 1 co: "agere sequitur ad esse perfectum, cum unumquodque agat secundum quod est in actu." Also Summa Contra Gentiles, lib. 3 cap. 69 n. 20: "agere sequitur ad esse in actu." For Aquinas's texts, I have relied on Corpus Thomisticum. S. Thomae de Aquino Opera Omnia. Edited by Enrique Alarcón. Pamplona, 2000. Online at http:/ / www.corpusthomisticum.org/iopera.html. Translations are my own.

4 Summa Theologiae (III 34.2 ad 1): "esse est prius natura quam agere."

5 Summa Theologiae (I.II 55.2 ad 1). 
However, for this very reason, Aquinas cannot be described as proposing an agent-rather than act—centered ethics. If we need the virtues precisely as principles of operation, then operation is also important, as their final cause. Activity is that for the sake of which virtue exists.

The act-orientation of Aquinas's virtue theory is evident in the important final-causal axiom, "every being exists for the sake of its operation". ${ }^{6}$ Again, this is a metaphysical principle intended to apply universally to all created beings; yet, once again, it has significant implications in ethics. Aquinas deduces from this axiom that, in the case of the human person, it is precisely through operation, rather than merely habit, that the human person reaches her end. ${ }^{7}$ In Aquinas's technical language, the first actuality (habit), as incomplete, exists for the sake of second actuality (activity), the more complete, ${ }^{8}$ just as the musician's art exists for the sake of playing (and the goods that follow upon playing). The underlying metaphysics is one in which a substance, like a human being, reaches its fullest state of actualization precisely in operation, in activity. As Cajetan explains, "To say, 'Each being having an operation exists for the sake of its operation,' is to say nothing other than that it exists for the sake of itself in complete and perfect actuality". 9 (Emphasis added.)

This principle makes for a dynamic, rather than static virtue theory. Sometimes, virtue ethicists make it sound as though the ethical aim is to become virtuous. For example, one common way of explaining virtue ethics is that it asks three questions: "Who am I?" "Who should I become?" "How do I get there?" (Kotva 1996, p. 22) However, for Aquinas, the end of life is not a habit, but an activity; hence, virtue by itself cannot be the goal of life but only what orients us to that end. Following Aristotle, he notes that virtue does not lead to felicity if one lacks the opportunity to exercise it, or if one is asleep! $!^{10}$ The end of life is not merely to become good, but to become good-in-action.

The primacy of activity in Aquinas's virtue theory is seen also in his striking claim that, while in a certain sense virtue is better than an action, since it potentially or virtually contains within itself many good actions, strictly speaking a good act is better than the corresponding virtue. ${ }^{11}$ He gives two reasons: first, it is better to act well than to be able to act well; and secondly, the goodness of a virtue derives entirely from its being an inclination to a good act, which is therefore more foundational. In sum, then, "operation according to virtue is more perfect than virtue itself". ${ }^{12}$ Aquinas's virtue theory, then, is act-oriented in that operation is recognized as the final cause of virtue. ${ }^{13}$

So far, so philosophical. However, an underlying theological commitment is discernible in the way Aquinas sees virtue as referring, ultimately, not merely to the agent or the act, but beyond both. For the story of final causality does not stop with the act itself. Aquinas makes a distinction between two kinds of end, or rather, two aspects of any end: "the end is said in two ways: namely, the thing itself [ipsa res] that we desire to attain, and the use, namely, the attainment or possession of that thing". ${ }^{14}$ In other words, there is the end as what ultimately is to be attained and as its very attainment. Does, then, the foundational axiom, "each thing exists for the sake of its operation," say that virtuous activity is the ultimate terminus of virtuous desire, that is, the thing itself that is desired, or merely the attainment of some further end? Cajetan offers the following answer:

6 On the Virtues (1.9c): "omnis res est propter suam operationem." See especially Summa Theologiae I 105.5c, but also I 65.2c; 73.1.c; I.II 3.2.c; $49.3 \mathrm{c}$ ad 3 and 4 ad 1; II.II 9.1.c and ad 1; 32.4c.

Summa Theologiae I.II 3.2c.

Summa Theologiae I 105.5c.

9 Cajetan (Tommaso de Vio), "Commentary on the Summa Theologiae," in Sancti Thomae de Aquinas Opera Omnia Iussu Impensaque Leonis XIII, vol. 6. (Rome: Editori di San Tommaso, 1882), p. 30: “Ita quod unumquodque habens operationem esse propter suam operationem, nihil aliud est quam esse propter seipsum in actu completo et perfecto." Notwithstanding the criticisms of Cajetan by Selling and others, I take it as obvious that his classic commentary on the Summa Theologiae can often be enlightening.

10 Commentary on the Ethics, lib. 1 1. 5 n. 13.; On the Virtues (1.1 ad 4).

11 Summa Theologiae I.II $71.3 \mathrm{c}$ and ad 1.

12 Commentary on the Ethics, lib. 11. 12 n. 14.

13 See also the helpful discussion in David A. Horner, “Is Aquinas an Act-Ethicist or an Agent-Ethicist?" (Horner 2006).

14 Summa Theologiae I.II 2.7c. 
"[E]ach thing exists on account of its operation" could mean two things. First, it could mean that each thing exists for its operation as the thing that is the end; and thus it is completely false [falsissimum]. Secondly, it could mean that each thing exists for its operation as its proper complement; and, in this sense, it is true. ${ }^{15}$

Cajetan's point is that operation is not the thing itself [ipsa res] that is desired: the operations of knowing and loving are only the end as the attainment of some further end, not the ultimate end itself, the object that is known and loved. As Aquinas puts it, the end, the thing itself to be attained, that in which beatitude lies, exists "outside of the soul", extra animam. ${ }^{16}$

This has important implications. Admittedly, virtue theory will focus primarily on the virtues and their role in human life. However, virtue theory should not recommend the attainment of virtue, or even virtuous activity, as the primary ethical motivation or point of moral attention, since that would be to fall into a narcissistic moral perfectionism. As theological ethicist William Spohn suggests, "The virtuous life shifts attention from personal perfection to more important concerns" (Spohn 1999, p. 13). Similarly, philosopher Christine Swanton notes that it is right to have a "background desire" to be virtuous, but that virtuous people have as "foreground motivations" such things as desires to help friends for their own sakes (Swanton 2003, p. 29). While a desire to grow in virtue is one commendable aspiration among others, we should not fixate on how virtuous we are becoming, as though every morning we should get up and weigh ourselves on the scale of virtue and vice to see how well we have progressed, or how badly we have regressed. Such moral obsession is neither praiseworthy nor, ironically, is it the path to virtue.

Aquinas rightly denies, then, that the overriding, foreground motivation should be to possess the virtues, or even to live virtuously. His reasons for denying this are theological as well as philosophical, having to do with the Christian understanding of the virtue of love or charity, caritas. Aquinas distinguishes four levels or grades of possession of this virtue, according to the focus of a person's studium, her striving and attention. Beginners focus on avoiding sin; those who are progressing do principally attend to increasing in the virtue of love; but the advanced, in a scriptural phrase, "desire to be dissolved and to be with Christ". ${ }^{17}$ Finally, in heaven, "the whole heart of a human person is always actually borne towards God". ${ }^{18}$ As with all developmental models, these stages should not be taken too schematically. However, the model does show that, for Aquinas, growth in virtue shifts the focus from self to the other: the end-point and perfection of virtue is self-forgetfulness and being "always actually borne towards God". As Aquinas explains elsewhere:

It is necessary for the perfection of charity not only to abandon exterior things, but even in some way to abandon oneself. For [Pseudo-]Dionysius says (On the Divine Names, Ch. 4), that "divine love produces ecstasy", that is, it places a human being outside himself, not allowing a human to be for his own self, but for the beloved. ${ }^{19}$

Aquinas's theological, developmental virtue theory recommends an attentiveness and desire that grows from being act-focused to being also agent-focused, and finally to being other-focused. What Aquinas proposes, in the end, is an ecstatic virtue theory.

This reading of Aquinas and Cajetan suggests that to say that virtue theory is necessarily agent-centered rather than act-centered is an over-simplification bordering on a misrepresentation. To focus on the virtues is indeed to concentrate on the being of the agent. Yet, the virtues are by nature oriented to act as to their end or final cause, that for the sake of which they have their being. Just as

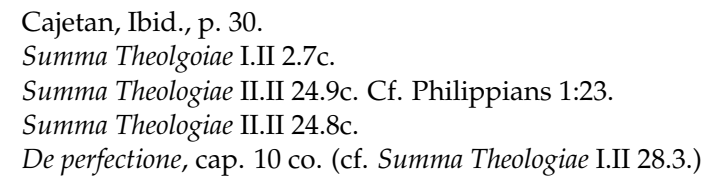


reference to an object is integral to a transitive verb, so reference to act is integral to virtue. ${ }^{20}$ And so virtue theory is also act-focused, insofar as it concerns habits that are, by their very essence, principles of virtuous operation. Finally, it helps, with Jorge Garcia, to make an important distinction: "Virtues may be seen as the proper focus of the moral subject's attention, or, alternatively, it can be claimed that virtues are the proper focus of the moral theorist's attention" (Garcia 2010). On my reading, while virtue theory does legitimately focus its own attention on virtue, it does not recommend virtue as the overriding focus of attention for the moral subject. At most, moral subjects have a helpful background desire for virtue. A theological virtue theory, because of its understanding of the nature of theological love, is in a good position to recognize that the loving, compassionate, and just person is not focused primarily on her own moral state, but is self-forgetfully or "ecstatically" concerned with the other to whom love, compassion, or justice are due.

\section{Virtue Theory and the Moral Evaluation of Actions}

The moral manuals of Catholic moral theology, for all their faults, did manage to say a lot about which kinds of action were right, and which were wrong. Selling, while wanting to put some water between his own approach and that of the moral manuals, nevertheless recognizes the danger of an overcorrection that abandons the important task of evaluating specific behaviors (Selling 2016, p. 200). For some, however, virtue theory is impotent to contribute towards this important task. As Robert Louden puts it, "What sets [virtue ethics] apart from other approaches, again, is its strong agent orientation. So for virtue ethics, the primary object of moral evaluation is not the act or its consequences, but rather the agent" (Louden 1984, p. 228).

To begin to question this assertion, it helps to return to the paper widely credited as launching the return to virtue, Elizabeth Anscombe's, "Modern Moral Philosophy" of 1958 (Anscombe 1958). It is not always noticed that one of the primary reasons Anscombe advocates a recovery of the "thick" language of the virtues is precisely because our moral vocabulary for talking about the morality of actions had become too "thin". For her, it would be progress if, instead of labelling actions as "morally right" or "morally wrong", we named the kind or type of the action. When I challenge a friend for acting unjustly, I may do so lovingly, sensitively, wisely, and temperately; or alternatively, I may do so vengefully, insensitively, foolishly, and intemperately. Such moral descriptions of actions are clearly derived from virtue- and vice-terms. It is striking, then, that at the outset of the renewal of virtue, one of the primary reasons given for its return is precisely that virtue helps us to talk, not just about the character of the agent, but also about particular actions.

For confirmation that virtue theory has something to say about the ethics of actions, it helps, once again, to return to Aquinas. Aquinas offers an analysis of the morality of actions in the Summa Theologiae, when he comes to consider "the goodness and malice of human acts" (I.II $18 \mathrm{Pr}$ ). He approaches the topic through the question of "specification". Each particular deliberate action is either good or evil in its species (I.II 18.9). The question, then, is how to determine the moral species of an action. As Joseph Pilsner explains, "In moral theory, identifying a human action's kind is of considerable importance. Although in some instances making such a determination is relatively easy—it doesn't take a trained moralist to recognize flagrant cases of murder, stealing, or adultery-in other instances, the task can be a challenge" (Joseph 2006, p. 1). For Pilsner, this challenge is met by Aquinas's theory of moral action, insofar as he identifies the determinants of the moral species of a human action. However, while much ink has been spilled over the interpretation of Aquinas's theory of the specification of human actions in terms of their object, circumstances, and end, it is rarely explained what are the "species" or types of moral action to which he is referring. Because of Aquinas's tendency to abstract rigor, it is not easy to tell. In his treatise on the moral goodness and malice of human acts, Aquinas does offer a few examples: theft, adultery, almsgiving, vanity, and murder. From

20 I thank an anonymous referee for this comparison. 
this list alone, we may be forgiven for assuming that the vocabulary for describing moral character on the one hand, and moral action on the other, are disparate. However, Aquinas himself clearly sees an intimate connection. Theft and murder are acts of the vice of injustice; adultery expresses both unchastity and injustice; almsgiving is an act of the virtue of mercy; and vanity is referred back to vainglory, a vice opposed to magnanimity and humility. This helps to make sense of Aquinas's well-cited claim that "the whole subject-matter of morals may be reduced [reducta] to the consideration of the virtues" (I.II Pr.). Whatever moral descriptions we give of particular actions may be "reduced", that is "led back" to the language of virtues and vices.

Like Aquinas, a number of contemporary virtue theorists have stressed the relationship between the virtues and particular actions. They have done so primarily by offering a virtue-based answer to the question, "What makes a right action right, and a wrong action wrong?" For example, according to Rosalind Hursthouse, "An action is right iff it is what a virtuous agent would characteristically (i.e., acting in character) do in the circumstances" (Rosalind 1999). Such accounts have been criticized on various grounds. If a right action is what a virtuous person characteristically would do, then it can never be right to express contrition, or to seek to become a virtuous person, or ask for guidance from someone wiser than myself, or force myself to be self-controlled, since a virtuous person may never have to do these things (Johnson 2003). More promising is Jorge Garcia's approach, which eliminates any counterfactual reference to what the virtuous person would do. For him, "acting wrong is acting viciously, and ... we can understand someone's acting rightly (in the minimal sense of behaving permissibly) as conducting herself in a way that is not genuinely vicious in any way in the situation" (Garcia 2010, p. 106). Presumably, then to act rightly in the positive sense of doing morally well, is simply to act virtuously. To the objection that we judge actions as wrong (or right), not so much by using vice- and virtue-language, as by appealing to certain action descriptions, Garcia replies: “we notice that we typically judge these types of action wrong by linking them to vices (or, at least, to vicious inputs). Thus, we explain that stealing and murder are wrong in that they are unjust, that lying is immoral because dishonest, that torture is cruel, adultery disloyal, and other forms of behavior weak-willed, cowardly, inconsiderate, and so on ... [T] hese vice terms present the way in which each type of action is moral wrong" (Garcia 2010, p. 106). Like Aquinas, Garcia traces the moral descriptors of actions back to the language of the virtues and the vices. Virtue theory is therefore able to contend with consequentialist and deontological normative ethical theories in offering an account of morally right and wrong actions.

Far from having nothing to say about actions, therefore, it is to virtue theory that we need to look to provide the thick moral language that both describes individual actions, and, as Garcia argues, explains the way in which actions are right or wrong, morally good or bad. For this reason, theological ethics needs virtue theory, not merely to describe the character of the moral subject, but even to characterize her behaviors.

\section{Virtue Theory, Action-Guidance, and Vagueness}

It is often claimed that virtue theory is too vague to be of normative or action-guiding significance. Louden puts the objection as follows: "people have always expected ethical theory to tell them something about what they ought to do, and it seems to me that virtue ethics is structurally unable to say much of anything about this issue. If I'm right, one consequence of this is that a virtue-based ethics will be particularly weak in the areas of casuistry and applied ethics" (Louden 1984, p. 229). It is odd, however, that those who continue to object in this way do not advert to the increasingly vast literature applying virtue ethics to various issues and fields of practice. ${ }^{21}$

21 See, for example, Rebecca L. Walker and P. J. Ivanhoe, eds., Working Virtue: Virtue Ethics and Contemporary Moral Problems (Walker and Ivanhoe 2007). 
A defense of virtue theory's directive potential may begin with Hursthouse's observation that virtue theory provides what she calls v-rules: "not only does each virtue generate a prescription-act honestly, charitably, justly — but each vice a prohibition—do not act dishonestly, uncharitably, unjustly" (Rosalind 2003, p. 190). There is, then, an implicit prescriptivity to the concepts of the virtues and the vices. Moreover, I believe that it is possible to improve upon Hursthouse's v-rules. I have argued elsewhere that, on one reading of Aquinas, a virtue can be analyzed according to a number of distinct elements (Austin 2017). Without going into the details of the theory, a rule such as "be temperate" can be unpacked into something like the following: "When faced with emotional attractions to food, drink, sex, consumer goods, etc., modulate those attractions to meet need rather than luxury (where 'need' refers to what is necessary to live a humanly fitting bodily, relational, and moral life), by restraining or positively rechanneling these desires through practices such as fasting and grateful enjoyment, thereby, even in one's appetites, following, dying, and rising with Christ". If we thinly characterize a virtue like temperance as something like "moderation", it will indeed be too vague to offer much normative guidance. Yet a thicker description, of the kind that Aquinas offers, implicitly contains a great deal of normative guidance. The v-rule, "Be temperate", warns us that there are certain characteristic objects in human life that elicit strong emotional attractions, which have the tendency to overrun their bounds and become destructive of the human good for self and others; that there is consequently a basic moral task in life to modulate these attractions in a way that contributes to a morally good, flourishing human life; that often this modulation will involve setting due limits, or redirecting one's attractions towards other objects; and that bodily practices such as fasting will often be necessary, although it is important also to avoid Manichaeism by finding a place for grateful celebration of the good gifts and pleasures God provides through his creation; and that this mortification and rising to new life of appetite is one aspect of a life patterned on Christ's. Virtue concepts are highly condensed packets of normativity, encoding a rich tradition of practical wisdom about how best to respond in some field of thinking, desiring, and acting. Through reflection on experience, we grow in the ability to recognize how the practical wisdom specific to each moral virtue is to be specified in concrete situations. The more deeply we understand the virtues, the more the v-rules, then, can guide us in how to live.

Garcia, like Hursthouse, connects virtue and moral rules, but in an even more integral way. He notes, following Henry Richardson, that norms should be formulated so that they are "transparent": "it is a desideratum of the formulation of any norm - that is, the statement of some obligation, permission, and the like- that it be transparent, making explicit on its face not just that some course of action is forbidden, but also why it is. This renders the norm more accessible, comprehensible, and open to our efforts at interpretation and justification" (Garcia 2010, p. 104). For Garcia, virtue- and vice-terms present the best candidates for making a norm transparent. Parents know this intuitively: "Be generous and share your sweets", "Don't shout, that's disrespectful”, and so on. It is not merely, then, that virtue and vice terms generate v-rules or norms, but that moral norms themselves are best expressed in terms of virtues and vices, as they make moral rules "transparent". Once again, the dichotomy between normative ethics and virtue theory looks increasingly questionable.

It may be objected that, even given the guidance of v-rules, or rules formulated by reference to virtue- and vice terms, virtue theory of itself fails to provide us exact guidance on what we should do in concrete situations. When faced with a difficult dilemma, it is not always clear what is the virtuous thing to do. This objection may rest upon the illusory search for the perfect normative theory, one that provides a "decision procedure", able to tell us how to act rightly in any conceivable situation. Hursthouse asks a disarming question: Supposing a very clever teenager became proficient at applying such a normative theory, would you go to her for moral counsel (Rosalind 2003, p. 193)? That we would not is a sign that we know that moral wisdom about how to act in the concrete circumstances of a person's life cannot be reduced to mastery of an algorithm or rulebook. Ethical theory, we may hope, can serve in the cultivation of the virtue practical wisdom; it cannot bypass it in directing action here and now. At best, ethical theory is like a military strategist directing things from afar: whatever guidance it gives, it has to leave some space for the final judgement to the soldier on the ground. 
The irreplaceability of the moral subject's judgement in concrete situations is also recognized by Aquinas:

And since the discussion of morals even in general terms is uncertain and variable, it becomes yet more uncertain if someone wants to descend further [to particulars], offering teaching specifically about singulars. For this does not fall under art, or under any narration, because the cases of singular actions vary in infinitely many ways. And so the judgment about particulars is left to the prudence of each. ${ }^{22}$

This passage comes from Aquinas's Commentary on the Nicomachean Ethics, and so may seem merely to be the working out of a philosophical insight into the impossibility of a perfectly codified ethics. Yet, once again, it is possible to detect in Aquinas here his dependence, not just on the Philosopher, but on a more theological, spiritual tradition, in this case that of discernment or "discretion", stretching back to Gregory the Great, Augustine, and Cassian. ${ }^{23}$ It is through discernment that one interiorly comes to understand and accept what God is asking one to do. Given the surprising and unpredictable nature of God's invitation in a particular human life-something with which Aquinas was intimately familiar, persisting in a vocation to Dominican religious life despite strong parental opposition-discernment of what ought to be done cannot always be reduced to the application of general rules to a particular circumstance (Endean 2004, pp. 106-11). It is therefore unsurprising that Pope Francis, in his Apostolic Exhortation, Amoris Laetitia, appeals both to Aquinas and the idea of discernment to avoid a reductive, rule-based approach to complex moral and pastoral questions: "It is reductive simply to consider whether or not an individual's actions correspond to a general law or rule, because that is not enough to discern and ensure full fidelity to God in the concrete life of a human being" (Pope Francis 2016). The spiritual tradition of discernment is a bulwark against an unduly legalistic or overly codified approach to moral decision making.

\section{Conclusions}

This essay, by taking Thomas Aquinas as a primary reference point, has attempted to delineate something of the contribution of virtue theory to theological, normative ethics, as well as the contribution of theological ethics to the theory of virtue. To see virtue theory as primarily focused on character is to underestimate the way virtue theory can assist theological ethics in its task of evaluating moral actions and thereby offering the right degree of action guidance, neither being too vague to be of any help, nor attempting to control what should be left to the prudential, discerning judgement of the situated moral subject. Theological ethics can warn virtue theory away from a narcissistic moral perfectionism by its insight into the ecstatic nature of fully mature virtue, as manifest most clearly in the theological virtue of love. A specifically theological ethics can also help to resist the misguided attempt at complete codifiability in moral decision making through its respect for the practice of spiritual discernment, which searches for knowledge of the ever-surprising will of God in the particularities of a person's life. Just as a genuinely normative virtue theory enriches theological ethics, so theological ethics may contribute to the theory of virtue.

Acknowledgments: This study was not funded. The author is grateful for reviewer comments on an earlier draft of this paper.

Conflicts of Interest: The author declares no conflict of interest.

\section{References}

Anscombe, Gertrude E. M. 1958. Modern Moral Philosophy. Philosophy 33: 1-19. [CrossRef]

22 Commentary on the Ethics, lib. 21. 2.5.

23 On the history of discernment, see McIntosh, Mark, Discernment and Truth: Meditations on the Christian Life of Contemplation and Truth (McIntosh 2004). 
Austin, Nicholas. 2017. Aquinas on Virtue: A Causal Reading. Moral Traditions Series; Washington: Georgetown University Press.

David Carr, James Arthur, and Kristján Kristjánsson, eds. 2016. Varieties of Virtue Ethics. London: Palgrave Macmillan.

Cloutier, David, and William C. Mattison III. 2014. Review Essay: The Resurgence of Virtue in Recent Moral Theology. Journal of Moral Theology 3: 228-59. [CrossRef]

Endean, Philip. 2004. Karl Rahner and Ignatian Spirituality. Oxford: Oxford University Press.

Garcia, Jorge L. A. 2010. The Virtues of the Natural Moral Law. In Natural Moral Law in Contemporary Society. Edited by Holger Zaborowski. Washington: Catholic University of America Press, p. 101.

Horner, David A. 2006. Is Aquinas an Act-Ethicist or an Agent-Ethicist? The Thomist 70: 237-65. [CrossRef]

Rosalind, Hursthouse. 1999. On Virtue Ethics. Oxford: Oxford University Press.

Rosalind, Hursthouse. 2003. Normative Virtue Ethics. In Virtue Ethics. Edited by Stephen L. Darwall. Oxford: Wiley-Blackwell.

Johnson, Robert N. 2003. Virtue and Right. Ethics 113: 810-34. [CrossRef]

Keenan, James F. 2008. A History of Catholic Moral Theology in the Twentieth Century: From Confessing Sins to Liberating Consciences. London: Continuum.

Kotva, Joseph J. 1996. The Christian Case for Virtue Ethics. Washington: Georgetown University Press.

Lawler, Michael G., and Todd A. Salzman. 2013. Virtue Ethics: Natural and Christian. Theological Studies 74: 442-73. [CrossRef]

Louden, Robert B. 1984. On Some Vices of Virtue Ethics. American Philosophical Quarterly 21: 228-29.

Mahoney, John. 1987. The Making of Moral Theology: A Study of the Roman Catholic Tradition. The Martin D'Arcy Memorial Lectures, 1981-2. Oxford: Clarendon Press.

McIntosh, Mark. 2004. Discernment and Truth: Meditations on the Christian Life of Contemplation and Truth. New York: Crossroad.

Joseph, Pilsner. 2006. The Specification of Human Actions in St. Thomas Aquinas. Oxford: Oxford University Press.

Pope Francis. 2016. Amoris Laetitia. Available online: http://w2.vatican.va/content/francesco/en/ apost_exhortations/documents / papa-francesco_esortazione-ap_20160319_amoris-laetitia.html (accessed on 19 March 2016).

Selling, Joseph A. 2016. Reframing Catholic Theological Ethics. Oxford: Oxford University Press.

Spohn, William C. 1999. Go and Do Likewise: Jesus and Ethics. New York: Continuum.

Swanton, Christine. 2003. Virtue Ethics: A Pluralistic View. New York: Oxford University Press.

Rebecca L. Walker, and P. J. Ivanhoe, eds. 2007. Working Virtue: Virtue Ethics and Contemporary Moral Problems. Oxford: Clarendon Press.

(C) 2017 by the author. Licensee MDPI, Basel, Switzerland. This article is an open access article distributed under the terms and conditions of the Creative Commons Attribution (CC BY) license (http://creativecommons.org/licenses/by/4.0/). 